\title{
A Proposed Model for Predicting the Financial Failure of Companies Using Partial Least Square Logistic Regression (Comparative study between Algeria and Jordan)
}

\author{
Dr.Fatima Zohra Kerroucha ${ }^{\# 1}$ Dr.Mohamed Bensaid ${ }^{\# 2}$ Halim Naimi $^{* 3}$ \\ Dr. Turki ELhamoud"4 \\ ${ }^{\#}$ Djillali liabes University -Department of economic sciences- Sidi Bel Abbes-Algeria \\ *Belhadj Bouchaib center university Ain temouchent-Department of management-Ain temouchent-Algeria \\ Yarmouk university- Department of accounting- Irbid- Jordan"
}

\begin{abstract}
This study aimed to find a model consisting of a set of financial ratios in which each ratio has its own weight that indicate its importance in discriminating between distressed and non-distressed firms in both Algeria and Jordan. The early prediction of industrial firm's distress warns the concerned parties that they can intervene and take corrective actions before the collapses of institution. To achieve this, twenty seven ratios were calculated for 1 to up 3 years before actual distress for a sample of thirty eight Jordanian industrial firms, half of which had failed and twenty four Algerian enterprises (eight bankrupt enterprises and sixteen nonbankrupt enterprises). These ratios were analyzed using the partial least square logistic regression to reach the best form of financial ratios that can distinguish between distressed firms and non-distressed firms in one year at least before failure. It has already been reached that the best model in predicting corporate failure is the model which was built in the first year before distress and which included twelve financial ratios, has been able to this form of re-classification of industrial companies to distressed companies and non-distressed companies with accuracy amounted to $92.9 \%$ in this year for the Jordanian companies and the determining coefficient of this model which expresses its goodness of fit has reached $90.4 \%$. To ensure the ability of this model to predict failed industrial companies and non-failed industrial companies, it was tested on another sample of industrial companies (out of sample) of ten firms half of which had failed enabling the model to distinguish between these companies accurately amounted to $90 \%$ in the first year before distress. The statistical results show that the logistic regression model is $95.7 \%$ accurate to predict Algerian enterprises financial distress and we can generally use three variables (net profit to sale, return on asset, net profit to total liabilities) in firm's financial distress prediction.
\end{abstract}

Keywords: Prediction, Distress, Financial ratios, Industrial firms, enterprises, Algeria, Jordan, Partial least Square Logistic regression.

\section{Introduction}

The topic of predicting financial failure of the institutions is one of the important issues that have held many international bodies and organizations, because of its negative effects on institutions and investors and at the level of the economy as a whole, and the importance of financial forecasting due to being an important tool lies in helping economic decisions makers in making their investment decisions or funding appropriately and properly, in addition to the financial forecasting helps in reducing the degree of uncertainty and worked on the potential for the future risk assessment.

As a result of the emergence of many changes and developments in the global economy and of the accelerated pace of globalization and global economic integration and opening-up policies and market liberalization and the emergence of the World Trade Organization and the partnership with the European Union, small medium sized enterpriseshave become an appropriate means to achieve local development, if it possesses a great investment incentives and inexpensive, able to expand the dynamic economic activity of the countries.

The great importance of small and medium enterprises are mainly due it`s multiple capabilities, they are working to meet local consumer needs, provide jobs, increase the spirit of competition between institutions, thereby improving the local product. All this made the developed countries are working on appropriate and necessary climate to provide for the growth of this sector .

Since the distress phenomenon became facing many economic institutions in any country in the world, due to internal factors or external attacks on the institutions of the weakness of the management or high debt and low profitability and weak financial structure and the inability to debt collection and other, small and medium enterprises will like any exposed economic institution of the previous mentioned factors which lead to find the latter. 
Due to the negative effects of the faltering institutions on the economy and on all groups operating in it and associated with these institutions, it has become necessary to find and develop a set of early warning detection of faltering before it happens and try to reduce the negative effects as much as possible if it falls .

Hence the need to predict a failure of institutions to be able administration and authorities stockholders to take appropriate corrective decisions in a timely manner to restore the health of these institutions.

(Ross et al, 2002) say that to understand distress, it should differentiate between distress and financial failure, and so as that the financial distress case precede the financial failure was not necessarily the result, and based on this distinction to the use of standard financial flexibility, and therefore considered that the distress means one of these two or both cases, namely:

- $\quad$ Lack of stock returns or stopped .

- $\quad$ stop paying obligations.

But the financial failure means one or both of those two cases, namely:

- totally stop paying obligations.

- $\quad$ bankruptcy and ceased activity.

Based on the foregoing, and for the purposes of this study and its objectives, the researchers in the classification of distressed institutions on the basis of those that have made losses for three consecutive years, because the successive losses in the enterprise indicates poor conditions and she is going to collapse.

\section{Problem of the Study}

The problem of the study Highlights of the need of many parties of investors, lenders and auditors, and others, to see the company's ability to survive and continuity away from failing due to the negative impact of distress companies on the national economy. Since there is no indication to the use of industrial companies in Jordan and Algeria and those interested in a model consists of a set of financial ratios to predict the distress of these companies before it happens.

Accordingly, this study raises many questions which they can inference about the importance of the problem of the study:

1. You could develop a mathematical model is able to distinguish between distressed companies and nondistressed companies in the first year before distress using PLS logistic analysis in Algeria and Jordan?

2. You could develop a mathematical model is able to distinguish between distressed companies and nondistressed companies in the second year before distress using PLS logistic analysis in Jordan?

3. You could develop a mathematical model is able to distinguish between distressed companies and nondistressed companies in the third year before distress using PLS logistic analysis in Jordan?

4. Will the proposed model built in the first year in Jordan, which will be reached accurately distinguish between distressed companies and non-distressed in the test sample, in the first year before faltering?

\section{The Objective of the Study}

This study aims to develop a mathematical model using the partial least square logistic analysis, consisting of a set of financial ratios, where each percentage of them weighing weighted, which reflects the degree of importance in predicting the distinction between industrial companies, before tripping one year at least, to be used in predicting distress of Jordanian industrial companies and Algerian enterprises. The objectives of the study can be summarized in the following points:

1. The main objective of this study is to try to develop a model consisting of a set of financial ratios for each of the three years preceding the distress using partial least square logistic regression to distinguish between industrial companies distressed and non-distressed companies.

2. Test the model's ability to predict and apply it to another sample of industrial companies, which did not make it in the construction of the proposed model, in the first year before distress.

\section{The Importance of the Study}

This study is gaining importance first of the importance of the industrial sector and its role in the national economy to be considered an indicator of economic development indicators.

Second of the interest applied to the model quantitative that study aims to develop when analyzing the published financial statements of the companies, and the possibility of universal use of this model in the Jordanian and Algerian industrial sector, which will add a new financial indicator can be relied upon by investment decision makers.

The study highlights the importance of practice in that predict the distress before hindsight gives an early warning about the risk of default, hence predict corporate distress before a period stumbling of many benefits for many stakeholders. 
The prediction of distress enables investors to identify the fate of their investments and the disposal of investments in companies that are going in the way of failure and directing their investments to companies that are not expected to failure, and also can creditors reassurance on loans granted to companies and make decisions granting new credit. As for management, it can eliminate the causes of distress before they rise and take the necessary corrective decisions, and for auditors, they can identify the company's ability to continuity and, finally, even the government can exercise its regulatory function to the fullest, allowing them to intervene in a timely manner.

\section{The Literature Reviews}

Many of the studies in most countries, the global developed and undeveloped countries dealt the subject of financial distress and ways to predictit, where many of those studies tried devise models appropriate to find models suitable for predicting bankruptcy or failure of companies in most sectors in the countries of the world, and will be reviewed in chronological order her:

Studies create models to predict the failure of companies has begun in the late sixties of the last century. One of the first studies in this field as the study of Beaver, which used the analysis of single variables and compare 14 financial ratios of companies failed to a group of successful companies and concluded that the financial ratios of the companies failed different financial ratios for companies successful, and that the cash flow to debt ratio was the most important ratio to distinguish between these companies .Instead of them, Altman has used 22 financial ratios in building a financial analysis model discriminatory multi variables .He has reached a model that can predict the failure of companies in the year prior to the occurrence, using several financial ratios together with accurately arrived to $95 \%$.

\section{Example of these studies [1]Study (Al-Khatib and Al-horani, 2012)}

This study aimed to reach the best possible range of financial indicators that can be used to predict a financial distress of public companies listed in Amman stock exchange by using two statistical models discriminant analysis and logistic regression. To achieve this, twenty four ratios were analyzed for a sample of fifty six companies (eighteen healthy companies and thirty eight distressed companies) for the period (20072011).

The study found that the discriminatory model witch contains four financial ratios: return on equity, retained earnings to total asset, fixed asset to equity right, net profit after tax to total asset, logistic model witch contains three ratios: return on equity, fixed asset to equity right, net profit after tax to total asset can predict the failure of public companies with an accuracy of $84.2 \%$ for healthy companies and $83.3 \%$ for distressed companies. The study concluded that the return on equity is the most able to predict financial failure in all the years of research.

\section{A. Study [5] (Lakshan et al, 2013)}

The purpose of this research is to develop a model using financial ratios to predict corporate failure of listed companies in Sri Lanka. This study has used fifteen financial ratios were used as predictor variables of corporate failure for a sample of seventy failed firms and seventy non-failed firms listed on Colombo market for a period (2002-2008) with a statistical methods known as logistic analysis.

The developed model contains three financial ratios: net working capital to total assets, cash flow from operation activities to total assets, total liabilities to total assets. The statistical results indicate that the prediction accuracy of the model is $77.86 \%$ in the first year before failure. Furthermore, predictive accuracy of the model in the second and third year prior to failure is $72.14 \%$ and $74.29 \%$ respectively.

\section{B. Study[11] (Zeytmoglu et al, 2013)}

This paper aims to develop reliable model to identify the financial failure risk of the firms listed on Istanbul Stock Exchange National-All Share Index. To achieve this goal twenty financial ratios were calculated for a sample of 115 firms for a period (2009-2011) by using discriminant analysis.

The first model developed in 2009 contains five financial ratios: net working capital to total assets, equity right to total assets, current assets to current liabilities, sale to total assets, account receivables to sales ratio, but the second model witch is developed in 2010 contains three financial ratios: net working capital to total assets, equity right to total assets, current assets to current liabilities. The third model developed in 2011 contains four financial ratios: net working capital to total assets, equity right to total assets, sales to equity right, total liabilities to equity right.

Capital adequacy and net working capital to total assets ratios are seemed to be significant in all three periods. According to formed models, classification success are determined as $88,7 \% 90,4 \%$ and $92,2 \%$ in 2009 , 2010 and 2011 years respectively. These high accuracy ratios indicate that the developed models for three years are efficient to determine the financial failure of the firms traded in Istanbul Stock Exchange. 


\section{Study [6] (Moghadas et al, 2014)}

This paper has studied the prediction firms financial bankruptcy in Tehran stock exchange by use of logistic model. Nine independent variables have been used in this research for a sample of fifty bankrupt firms and fifty non-bankrupt firms in Tehran stock exchange from 2002 to 2010.

The results show that the logistic regression model is $89.7 \%$ accurate to predict firm's financial distress and we can generally use four variables (total liabilities to total assets, current liabilities to total assets, net profit before tax to total assets, interest coverage ratio) in firm's financial distress prediction.

\section{Study [8] (Sharifabadi et al, 2014)}

This study was conducted to examine the ability of artificial neural network method to predict financial failure in the Tehran Stock Exchange. The study sample consisted of 47 failed company and 120 non-failed companies listed on the Tehran Stock Exchange for the period (2006-2011) through the analysis of 16 financial ratios derived from the financial statement of these companies.

The study was concluded that the developed model enables the re-classification of companies in the sample within the two groups of distressed and non-distressed categories with accuracy amounted 98.8\%, $97.3 \%, 95.2 \%, 94.2 \%, 93.2 \%$ in the first, second, and third, fourth and fifth years respectively before distress.

\section{The Hypothesis}

Based on the problem of the study and an investigation of its goal has been developed following hypotheses to be tested in this study:

1. The partial least square logistic model that consists of a set of financial ratios, which will be reached by using the regression method does not distinguish accurately between distressed companies and nondistressed companies in the first year before distress in the two countries.

2. The partial least square logistic model that consists of a set of financial ratios, which will be reached by using the regression method does not distinguish accurately between distressed companies and nondistressed companies in the second year before distress in Jordan.

3. The logistic model that consists of a set of financial ratios, which will be reached by using the regression method does not distinguish accurately between distressed companies and non-distressed companies in the third year before distress in Jordan.

4. The first logistic model does not distinguish accurately between distressed companies and non-distressed companies in the test sample in Jordan.

\section{A. The Population and the Sample of Study \\ Jordanian population}

\section{The Methodology}

The study population consists of all industrial companies listed on the Amman stock exchange during the period (1995-2014), of which there are 94 companies, but 26 companies were excluded because it began its work after the year 2000, and therefore not have the financial statements during the study period.

It has been selected all failed companies, which has made losses for three consecutive years during the period (1995-2009). The total number of those companies 19 companies and then the other sample was selected from 19 industrial companies non-distressed.

The table (I) shows the sample analysis companies and the size of its assets and its financial situation during the years of the study.

Table I

\begin{tabular}{|l|l|l|l|}
\hline Company & Asset Size & $\begin{array}{l}\text { The year of the Losses for } \\
\text { the Failed Company and } \\
\text { the Profits for its Similar }\end{array}$ & Observation \\
\hline INOH & 60.975 .264 & $\mathbf{2 0 0 0 , 2 0 0 1 , 2 0 0 2}$ & $\begin{array}{l}\text { Failed Company Make } \\
\text { Losses for 3 Year Successive }\end{array}$ \\
\hline JODA & 60.184 .306 & $2000,2001,2002$ & $\begin{array}{l}\text { Non Failed Company } \\
\text { Similar to the Previous }\end{array}$ \\
\hline NATP & 596.494 .183 & $\mathbf{1 9 9 7 , 1 9 9 8 , 1 9 9 9}$ & $\begin{array}{l}\text { Failed Company Make } \\
\text { Losses for 3 Year successive }\end{array}$ \\
\hline JOST & 596.273 .390 & $1997,1998,1999$ & $\begin{array}{l}\text { Non Failed Company } \\
\text { Similar to the Previous }\end{array}$ \\
\hline NAST & 118.941 .653 & $\mathbf{1 9 9 6 , 1 9 9 7 , 1 9 9 8}$ & $\begin{array}{l}\text { Failed Company Make } \\
\text { Losses for 3 Year Successive }\end{array}$ \\
\hline APHC & 117.808 .594 & $1996,1997,1998$ & $\begin{array}{l}\text { Non Failed Company } \\
\text { Similar to the Previous }\end{array}$ \\
\hline JSLC & 66.356 .292 & $\mathbf{2 0 0 0 , 2 0 0 1 , 2 0 0 2}$ & $\begin{array}{l}\text { Failed Company Make } \\
\text { Losses for 3 Year Successive }\end{array}$ \\
\hline
\end{tabular}




\begin{tabular}{|c|c|c|c|}
\hline UADI & 66.723 .486 & $2000,2001,2002$ & $\begin{array}{l}\text { Non Failed Company } \\
\text { Similar to the Previous }\end{array}$ \\
\hline APCT & 87.191 .259 & $2002,2003,2004$ & $\begin{array}{ll}\text { Failed Company } & \text { Make } \\
\text { Losses for } 3 \text { Year Successive }\end{array}$ \\
\hline JOPI & 88.037 .873 & $2002,2003,2004$ & $\begin{array}{l}\text { Non Failed Company } \\
\text { Similar to the Previous }\end{array}$ \\
\hline NDAR & 101.858 .192 & $2000,2001,2002$ & $\begin{array}{l}\text { Failed Company Make } \\
\text { Losses for } 3 \text { Year Successive }\end{array}$ \\
\hline NATC & 115.382 .175 & $2000,2001,2002$ & $\begin{array}{l}\text { Non Failed Company } \\
\text { Similar to the previous }\end{array}$ \\
\hline AMAN & 48.837 .475 & 2000 to 2006 & $\begin{array}{l}\text { Failed Company Make } \\
\text { Losses for } 3 \text { Year Successive }\end{array}$ \\
\hline PERL & 47.010 .833 & $2000,2001,2002$ & $\begin{array}{l}\text { Non Failed Company } \\
\text { Similar to the Previous }\end{array}$ \\
\hline WOOD & 143.624 .309 & $1997,1998,1999$ & $\begin{array}{ll}\text { Failed Company } & \text { Make } \\
\text { Losses for } 3 \text { Year Successive }\end{array}$ \\
\hline ENPC & 143.339 .797 & $1997,1998,1999$ & $\begin{array}{l}\text { Non Failed Company } \\
\text { Similar to the Previous }\end{array}$ \\
\hline TRAV & 42.662 .415 & $2001,2002,2002$ & $\begin{array}{l}\text { Failed Company Make } \\
\text { Losses for } 3 \text { Year Successive }\end{array}$ \\
\hline JOIC & 37.367 .485 & $2001,2002,2002$ & $\begin{array}{l}\text { Non Failed Company } \\
\text { Similar to the Previous }\end{array}$ \\
\hline IENG & 136.327 .534 & 2002 to2007 & $\begin{array}{l}\text { Failed Company Make } \\
\text { Losses for } 3 \text { Year Successive }\end{array}$ \\
\hline ASPMM & 147.699 .657 & $2002,2003,2004$ & $\begin{array}{l}\text { Non Failed Company } \\
\text { Similar to the Previous }\end{array}$ \\
\hline WIRE & 215.040 .890 & $2000,2001,2002,2003$ & $\begin{array}{l}\text { Failed Company Make } \\
\text { Losses for } 3 \text { Year Successive }\end{array}$ \\
\hline AIFF & 209.286.639 & $2000,2001,2002$ & $\begin{array}{l}\text { Non Failed Company } \\
\text { Similar to the Previous }\end{array}$ \\
\hline AEIN & 122.884 .189 & $1996,1997,1998$ & $\begin{array}{lll}\text { Failed Company } & \text { Make } \\
\text { Losses for } 3 \text { Year Successive }\end{array}$ \\
\hline UMIC & 120.191 .638 & $1996,1997,1998$ & $\begin{array}{l}\text { Non Failed Company } \\
\text { Similar to the Previous }\end{array}$ \\
\hline WOOL & 12.471 .925 & $2000,2001,2002$ & $\begin{array}{l}\text { Failed Company make } \\
\text { Losses for } 3 \text { Year Successive }\end{array}$ \\
\hline GENM & 24.025 .670 & $2000,2001,2002$ & $\begin{array}{l}\text { Non Failed Company } \\
\text { Similar to the Previous }\end{array}$ \\
\hline ICER & 123.456 .446 & 1996,1997,1998 & $\begin{array}{l}\text { Failed Company Make } \\
\text { Losses for } 3 \text { Year Successive }\end{array}$ \\
\hline JOIR & 124.113 .267 & $1996,1997,1998$ & $\begin{array}{l}\text { Non Failed Company } \\
\text { Similar to the Previous }\end{array}$ \\
\hline ICAG & 193.494 .568 & $2004,2005,2006$ & $\begin{array}{l}\text { Failed Company Make } \\
\text { Losses for } 3 \text { Year Successive }\end{array}$ \\
\hline GENI & 195.930 .596 & $2004,2005,2006$ & $\begin{array}{l}\text { Non Failed Company } \\
\text { Similar to the Previous }\end{array}$ \\
\hline INMJ & 14.237 .033 & 2003 to 2008 & $\begin{array}{ll}\text { Failed Company } & \text { Make } \\
\text { Losses for } 3 \text { Year Successive }\end{array}$ \\
\hline JOWL & 25.025 .873 & $2003,2004,2005$ & $\begin{array}{l}\text { Non Failed Company } \\
\text { Similar to the Previous }\end{array}$ \\
\hline JPPC & 125.498 .747 & $2006,2007,2008$ & $\begin{array}{lll}\text { Failed Company } & \text { Make } \\
\text { Losses for } 3 \text { Year Successive }\end{array}$ \\
\hline JVOI & 122.636 .144 & $2006,2007,2008$ & $\begin{array}{l}\text { Non Failed Company } \\
\text { Similar to the Previous }\end{array}$ \\
\hline $\begin{array}{l}\text { Jordanian } \\
\text { Dibarra }\end{array}$ & 38.615 .484 & 2005,2006,2007 & $\begin{array}{l}\text { Failed Company Make } \\
\text { Losses for } 3 \text { Year Successive }\end{array}$ \\
\hline UNIC & 31.214 .127 & $2005,2006,2007$ & $\begin{array}{l}\text { Non Failed Company } \\
\text { Similar to the Previous }\end{array}$ \\
\hline JOCF & 125.519 .354 & $2006,2007,2008$ & $\begin{array}{lcc}\text { Failed Company } & \text { Make } \\
\text { Losses for } 3 \text { Year Successive }\end{array}$ \\
\hline JOPC & 133.106 .342 & $2006,2007,2008$ & $\begin{array}{l}\text { Non Failed Company } \\
\text { Similar to the Previous }\end{array}$ \\
\hline
\end{tabular}

The researchers have selected non-distressed firm similar to distressed firm although the method adopted does not require that there is a similarity between distressed companies and non-distressed companies in terms of the type of sector and asset size, but the researchers prefer so as to obtain the results of accurate and objective.

The study focused on the financial statements for the three years of consecutive losses for distressed companies for the purposes of logistic analysis to can build a mathematical model consisting of a set of financial ratios able of predicting a stalled companies and for each of the three years, because the three-year period is 
sufficient to correct the financial situation in industrial companies to take corrective action to avoid financial distress (as in [4](Al-Omari, 2000) and then determine what is the best model can be relied upon to predict the phenomenon of distress.

It is worth mentioning that it is not sufficient to choose the best model among the three models, but it was tested the extent of the built model in the first year before faltering in the application on another sample of companies witch consists of all the other failed companies during the period (2009-2014). It has been shown that there are 5 companies made losses for three consecutive years, then was chosen other 5 companies similar to the five failed companies have to be included in the test sample (table II).

\section{Table II}

\begin{tabular}{|c|c|c|c|}
\hline Company & Asset size & $\begin{array}{l}\text { The year of the } \\
\text { losses for the failed } \\
\text { company and the } \\
\text { profits for its similar }\end{array}$ & Observation \\
\hline ACDT & 28.744 .789 & $2010,2011,2012$ & $\begin{array}{lrr}\text { Failed Company } & \text { Make } \\
\text { Losses for } 3 & \text { Year } \\
\text { Successive } & & \end{array}$ \\
\hline CJCC & 28.721 .796 & $2010,2011,2012$ & $\begin{array}{l}\text { Non Failed Company } \\
\text { Similar to the Previous }\end{array}$ \\
\hline JOSE & 12.949 .436 & $2010,2011,2012$ & $\begin{array}{lll}\text { Failed Company } & \text { Make } \\
\text { losses for } 3 & \text { Year } \\
\text { Successive } & & \\
\end{array}$ \\
\hline$\overline{\text { SLCA }}$ & 12.977 .929 & $2010,2011,2012$ & $\begin{array}{l}\text { Non Failed Company } \\
\text { Similar to the Previous }\end{array}$ \\
\hline$\overline{A Q R M}$ & 57.645 .617 & $2010,2011,2012$ & $\begin{array}{lrr}\text { Failed Company } & \text { Make } \\
\text { Losses for } 3 & \text { Year } \\
\text { Successive } & & \\
\end{array}$ \\
\hline HPIC & 65.782 .184 & $2010,2011,2012$ & $\begin{array}{l}\text { Non Failed Company } \\
\text { Similar to the Previous }\end{array}$ \\
\hline ASAS & 85.861 .354 & $2010,2011,2012$ & $\begin{array}{l}\text { Failed Company } \\
\text { Losses for } 3 \text { Yake } \\
\text { Successive }\end{array}$ \\
\hline AALU & 88.281 .452 & $2010,2011,2012$ & $\begin{array}{l}\text { Non Failed Company } \\
\text { Similar to the Previous }\end{array}$ \\
\hline JNCC & 374.950 .858 & $2010,2011,2012$ & $\begin{array}{lrr}\text { Failed Company } & \text { Make } \\
\text { Losses for } 3 & \text { Year } \\
\text { Successive } & & \\
\end{array}$ \\
\hline JOWM & 379.596 .547 & $2010,2011,2012$ & $\begin{array}{l}\text { Non Failed Company } \\
\text { Similar to } \\
\text { the Previous }\end{array}$ \\
\hline
\end{tabular}

\section{Algerian Population}

In this research, statistical population consisted of a group of small and medium-sized enterprises witch active in Sidi Bel Abbes and Oran state (Algeria) during the period (2005-2014) of witch there are 61 enterprises. The study sample consists of a group of failed institutions, and another set of non-distressed institutions. The researcherswere selected All bankrupt institutions, which achieved losses for three consecutive years during the period (2005-2014). The total number of those enterprises 8 institutions and then the other sample was selected from 16 enterprises non-failed. The table (III) shows the sample analysis companies and its financial situation during the years of the study.

Table III

\begin{tabular}{|l|r|l|}
\hline Company & $\begin{array}{l}\text { The year of the losses for the failed } \\
\text { company and the profits for its similar }\end{array}$ & Observation \\
\hline Sidhoum & $\mathbf{2 0 0 9 , 2 0 1 0 , 2 0 1 1}$ & Failed Company \\
\hline Broderie & $2009,2010,2011$ & Non Failed Company \\
\hline Glass & $\mathbf{2 0 0 8 , 2 0 0 9 , 2 0 1 0}$ & Failed Company \\
\hline Elkhaouter & $2008,2009,2010$ & Non Failed Company \\
\hline Sudest & $\mathbf{2 0 0 9 , 2 0 1 0 , 2 0 1 1}$ & Failed Company \\
\hline Mekahli & $2009,2010,2011$ & Non Failed Company \\
\hline Verrecom & $\mathbf{2 0 1 0 , 2 0 1 1 , 2 0 1 2}$ & Failed Company \\
\hline Abonnance & $2010,2011,2012$ & Non Failed Company \\
\hline Respao & $\mathbf{2 0 0 8 , 2 0 0 9 , 2 0 1 0}$ & Failed Company \\
\hline Inter Glass & $2008,2009,2010$ & Non Failed Company \\
\hline Taxi & $\mathbf{2 0 1 0 , 2 0 1 1 , 2 0 1 2}$ & Failed Company \\
\hline Ocilait & $2010,2011,2012$ & Non Failed Company \\
\hline Beriahi & $\mathbf{2 0 0 7 , 2 0 0 8 , 2 0 0 9}$ & Failed Company \\
\hline Medium & $2007,2008,2009$ & Non Failed Company \\
\hline SahrEcham & $\mathbf{2 0 0 9 , 2 0 1 0 , 2 0 1 1}$ & Failed Company \\
\hline
\end{tabular}




\begin{tabular}{|l|l|l|}
\hline EMIPSS & $2009,2010,2011$ & Non Failed Company \\
\hline Messer & $2009,2010,2011$ & Non Failed Company \\
\hline Casati & $2009,2010,2011$ & Non Failed Company \\
\hline Intelligence & $2009,2010,2011$ & Non Failed Company \\
\hline Mobicam & $2009,2010,2011$ & Non Failed Company \\
\hline Verr Pack & $2009,2010,2011$ & Non Failed Company \\
\hline Commembal & $2009,2010,2011$ & Non Failed Company \\
\hline Wahrania & $2009,2010,2011$ & Non Failed Company \\
\hline DjabelDoukh & $2009,2010,2011$ & Non Failed Company \\
\hline
\end{tabular}

\section{B. Statistical Analysis used in the Study}

To achieve this, twenty seven ratios were calculated for a sample of thirty eight industrial firms, half of which had failed for the Jordanian case, from its financial statement for each year of the three years of losses for the purpose of analysis. But for the Algerian case, this twenty seven ratios were calculated for the first year before distress for a sample of twenty four institutions (eight failed institutions and sixteen non-failed institutions).

These ratios were analyzed using the statistical method known as partial least square logistic regression to reach the best form of financial ratios that can distinguish between industrial distressed and non-distressed firms in one year at last before distress. We have summarized the independent variables in table IV.

Table IV

\begin{tabular}{|l|l|}
\hline Variables & Explanation \\
\hline X1 & Current assets to current liabilities \\
\hline X2 & Current assets mines inventory to current liabilities \\
\hline X3 & Cash to total liabilities \\
\hline X4 & Cash flow from operation activities to total liabilities \\
\hline X5 & Net working capital to total assets \\
\hline X6 & Cash flow from operation activities to total assets \\
\hline X7 & Net working capital to equity right \\
\hline X8 & Current assets to total assets \\
\hline X9 & Net profit after tax to sale \\
\hline X10 & Net profit after tax to total assets \\
\hline X11 & Net profit after tax to equity right \\
\hline X12 & Net profit after tax to net working capital \\
\hline X13 & Net profit after tax to total liabilities \\
\hline X14 & Net profit after tax to fixed assets \\
\hline X15 & Net profit after tax to sale \\
\hline X16 & Sale to total assets \\
\hline X17 & Sale to fixed assets \\
\hline X18 & Sale to equity right \\
\hline X19 & Sale to net working capital \\
\hline X20 & Sale to account receivables \\
\hline X21 & Equity right to total assets \\
\hline X22 & Equity right to fixed assets \\
\hline X23 & Total liabilities to total assets \\
\hline X24 & Equity right to total liabilities \\
\hline X25 & Equity right to current liabilities \\
\hline X26 & Interest coverage ratio \\
\hline X27 & Market value to book value of stock \\
\hline & \\
\hline
\end{tabular}

These ratios were unloaded at SPSS program in the form of variable numbered 27 variables so that each variable represents a certain financial ratio. Data were analyzed statistically using logistic analysis (Binary regression) as a method which is compatible with these data. One of the first studies to predict the failure of companies using this model, as in ([7], [10]).

Logistics analysis is used for classification or prediction in studies where the dependent variable is descriptive variable takes two values crossing them $(1,0)$, which is known as the binomial nominal variables, the case of distress takes the value of 1 and the case of no distress takes 0 , while independent variables it can be quantitative or nominal variables.

\section{The Result and Recommendation}

This study has found the following results:

\section{For the Jordanian case:}

- The model which was built in the first year before distress consists of 12 financial ratios: the quick ratio, cash flow to total liabilities, net profit before tax to sales, return on assets, return on equity, net profit to Net working capital, return on sales, fixed asset turnover ratio, internal funding ratio, equity right to fixed 
assets, total liabilities to total assets, then the equity right to total liabilities. The model enables the reclassification of companies that have been used in its design accurately amounted to $92.9 \%$. To ensure the ability of this model to predict distressed companies and non-distressed companies, was tested on another sample of 10 industrial companies (out of sample) half of them are failed and the other half is non-failed, its financial ratios was extracted in the first year before distress, enabling the model of discrimination between these companies accurately reached $90 \%$. It has been also testing the accuracy of this result in the classification by using the (T-test), results were statistically significant at the 0.05 level of significance.

- The model which was built in the second year before faltering consists of 7 financial ratios: the quick ratio, the proportion of cash flow to total liabilities, net profit to net working capital ratio, fixed asset turnover ratio, the proportion of domestic financing, equity rights to fixed assets ratio, then the ratio of equity rights to total liabilities. The model enables the re- classification of companies that have been used in its design accurately amounted to $91.2 \%$.

- The model which was built in the third year before distress contains 9 financial ratios: the quick ratio, the proportion of cash flow to total liabilities, the net profit to net working capital ratio, fixed asset turnover ratio, internal financing ratio, equity rights to fixed assets ratio, total liabilities to total assets, then the equity rights to total liabilities ratio, interest coverage rate. The model enables the re- classification of companies that have been used in its design accurately amounted to $83.9 \%$.

- The findings of the study indicated that the developed model in the first year before failure is a reliable and efficient model with accuracy rate $92.9 \%$ and coefficient of determination (as indicator of model's goodness of fit) cox \&snell coefficient and nagelkerke coefficient were 0.678 and 0.904 respectively, but the likelihood was (-2loglikelihood=7.102).

\section{For the Algerian case:}

- The model which was built in the first year before distress consists of three financial ratios: net profit before tax to total sales, return on assets, net profit after tax to total liabilities. The model enables the reclassification of institutions that have been used in its design accurately amounted to $95.7 \%$. This model is expressed as follow:

$$
\log (\text { odds })=-0.747-12.766 x_{9}-43.448 x_{10}-17.299 x_{13}
$$

- The findings of the study indicated that the developed model in the year of analysis is a reliable and efficient model with accuracy rate $95.7 \%$ and coefficient of determination (as indicator of model`s goodness of fit) cox \&snell coefficient and nagelkerke coefficient were 0.497 and 0.702 respectively, but the likelihood was (-2loglikelihood=12.468).

- The researchers have built three models for the Jordanian companies while they have built only one model for Algerian institutions because the financial statements for these institutions are not available for the three years preceding the distress.

- The researchers also can`t test the Algerian model to another sample (out of sample) to endure the ability of this model, because during the period of the study (2005-2008), they have found only eight bankrupt firm`s witch entered into the sample study.

\section{Recommendation}

The study finished with some useful recommendations. The most important of them is the utilization of the proposed model by the companies control department, Ministry of industry \& Trade, current and prospective investors and company management in order to predict financial failure of industrial companies in the two countries. The study also, recommended to bind companies need to submit their financial reports on time, so as to facilitate the collection of data by researchers to conduct studies on the subject of faltering especially in Algerian economic because the sample institutions used in this study are not listed in Algeria stock exchange. The study also recommended the inclusion of non-financial indicators such as firm size, its age, the various economic variables,...etc, as well as financial indicators such as financial ratios when building mathematical models to predict financial failure.

\section{References}

[1] Al-Khatib, Hazem and Al-horani, Alaa, "Predicting Financial Distress Of Public Companies Listed In Amman Stock Exchange", European Scientific Journal, Vol.8, No.15, pp 1-17, 2012.

[2] Altman, Edward I., "Financial Ratios Discriminant Analysis and the Prediction of Corporate Bankruptcy", Journal of Finance, Vol.23, No.4, pp 589-609, 1968.

[3] Beaver, William, "Financial Ratios as Prediction of Failure", Journal of Accounting Research, pp71-111, 1966.

[4] El-Omari, Ahmed Yahya, "The use of financial ratios to predict in the field of hotel industry in Jordan", unpublished master thesis, Al al-Bayt University, Mafraq, Jordan, 2000.

[5] Lakshan, Ishara and Wijekoon, Nisansala, (2013), "The Use of Financial Ratios in Predicting Corporate Failure in Sri Lanka", GTSF journal on business review (GRB), vol.2, No.4, pp 37-43. 
[6] Moghadas, HavvaBaradaran and Salami Elham, (2014), "Prediction Financial Distress By Use Of Logistic In Firms Accepted In Tehran Stock Exchange", Indian Journal Of Fundamental And Applied Life Science, Vol.4, No.1, April- June, pp 200-207.

[7] Ohlson, J., "Financial Ratios and the Probalistic Prediction of Bankruptcy", Journal of Accounting Research, Vol 18, No 2, spring, pp 109-131, 1980.

[8] Sharifabadi, Ali Morovati and Shahedi, SaeidehHedayati and Moeinadin, Mahmoud, "Analysis Of The Power Of Predicting Financial Distress Of Companies Listed In Tehran Stock Exchange Using Artificial Neural Networks", Interdisciplinary Journal Of Contemporary Research In Business, Vol.5, No.11, pp 181-188, 2014

[9] Ross, Westerfield and Jaffe, (2002), "Corporate Finance", McGraw-Hill Higher Education, Sixth Edition.

[10] Zavgren, C., "Assessing the Vulnerability to Failure of American Industrial Firms: A Logistic Analysis", Journal of Business Finance and Accounting, 12 (1), pp 19-45, spring 1985

[11] Zeytmoglu, Emin and DenizAkarim, Yasemin, (2013), "Financial Failure Prediction Using Financial Ratios: An Empirical Application On Istanbul Stock Exchange", Journal of Applied Finance \& Banking, Vol.3, No.3, pp 107-116. 